\title{
PENGUKURAN STRIKE DAN DIP DI DESA PADAELO' KECAMATAN MALLAWA KABUPATEN MAROS SULAWESI SELATAN
}

\author{
Ayusari Wahyuni, Nurul Fuadi, Sri Zelviani, Dya Ayu, Aminah, \\ Zilmi Azyurah, dan Fenty Nur ${ }^{1}$ \\ 1Jurusan Fisika, Fakultas Sains dan Teknologi, UIN Alauddin Makassar \\ Email: dyaayurahmaniar98@gmail.com, ayusari_wahyuni@uin-alauddin.ac.id, \\ nurul.fuadi@uin-alauddin.ac.id, sri.zelviani@uin-alauddin.ac.id
}

\begin{abstract}
It has been done field lectures to determine Strike and dip in the village in the ELO district, Mallawa Maros South Sulawesi Regency. The purpose of this lecture is to know the value of Strike and dip in the lecture site field. The methods used are methods of discussion, sampling and measurement. The tools used are geological compass, GPS, geological Hammer, ATK and meter. From the results of measurements obtained Strike and DIP N353oE/64o value at the location of the lecture field.
\end{abstract}

Keywords: Strike, dip, geological compass, geological structure.

\section{PENDAHULUAN}

Secara umum hal yang paling penting dalam mempelajari struktur geologi adalah geometri dari unsur struktur. Hal ini sangat penting, karena menyangkut lokasi pembentukannya, karakteristik, orientasi, dan evolusi dari unsur-unsur struktur tersebut.

Geologi struktur adalah suatu ilmu yang mempelajari perihal bentuk arsitektur kerak bumi beserta gejala-gejala geologi yang menyebabkan terjadinya perubahanperubahan bentuk (deformasi) pada batuan.Geologi struktur mencakup bentuk permukaan bentuk permukaan zang juga dibahas pada studi geomorfologi, metamorfosisi dan geologi rekayasa.

Kompas berasal dari bahasa Latin yaitu Compassus yang berarti jangka. Kompas sendiri sudah dikenal sejak 900 tahun yang lalu terbukti dengan diketemukannya kompas kuno yang dipakai pejuang China sekitar tahun $1100 \mathrm{M}$. Kompas geologi digunakan untuk mengukur arah (azimuth) pada suatu titik ataupun kelurusan struktur, mengukur kemiringan lereng, maupun mengukur jurus ataupun kedudukan perlapisan dan kemiringan lapisan batuan. Setiap kompas geologi harus memiliki sebuah jarum magnit, lingkaran pembagi dalam derajat, nivo leveling (nivo mata lembu) dan sebuah klinometer dengan nivo tabung mengukur kemiringan.

Strike atau jurus adalah arah garis yang dibentuk dari perpotongan bidang planar dengan bidang horizontal ditinjau dari arah utara. Dip adalah derajat yang dibentuk antara bidang planar dan bidang horizontal yang arahnya tegak lurus dari garis strike. Bidang planar ialah bidang yang relatif lurus, contohnya ialah bidang perlapisan, bidang kekar, bidang sesar, dan sebagainya. Dari uraian diatas maka 
dilakukan kegiatan kuliah lapangan dengan Tujuan untuk menentukan jurus (strike) dan kemiringan (dip) di lokasi kuliah lapangan.

\section{METODE PENELITIAN}

Identifikasi Strike dan dip di lakukan di Desa Pada Elo' Kecamatan Mallawa Kabupaten Maros pada hari Rabu tanggal 1 Mei 2019. Secara geografis titik koordinat lokasi kuliah lapangan adalah $4^{\circ} 50$ '36.19"LS dan 11953'1.02" BT. Berikut merupakan peta lokasi kuliah lapangan:

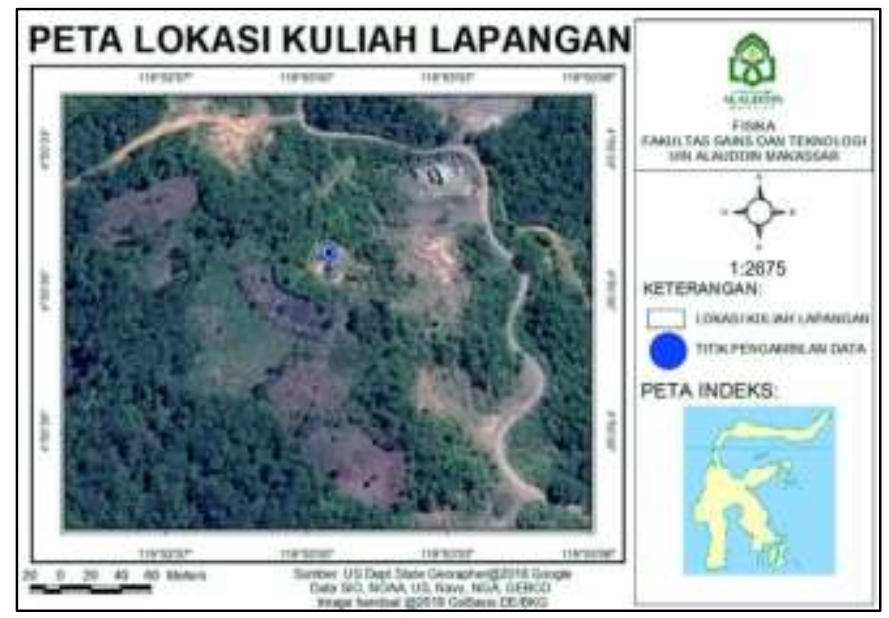

Gambar 1. Peta kuliah lapangan

Adapun alat dan bahan yang digunakan pada kuliah lapangan ini yaitu kompas geologi, GPS, palu geologi, ATK, meteran. Metode yang digunakan dalam kuliah lapangan yaitu:

1. Diskusi

Metode ini dilakukan untuk menentukan jenis lapisan yang terlihat secara kasat mata, kemudian membahas tata cara penggunaan kompas geologi yang digunakan untuk mengukur strike dan dip.

2. Pengukuran strike

Cara menentukan strike dengan menggunakan kompas geologi yaitu yang pertama, mencari batuan yang agak rata dapat menggunakan bantuan papan pengalas. Kedua, menempelkan sisi $\mathrm{E}$ (east) badan kompas kebidang batuan dengan lengan kompas searah dengan strike selanjutnya, mengatur badan kompas hingga gelembung udara pada Bull's eye tepat di tengah. Kemudian menekan tombol kecil yang berada dibadan kompas untuk mengunci posisi jarum kompas. Terakhir, membaca derajat yang ditunjukkan oleh jarum utara ( $\mathrm{N}$ ).

3. Pengukuran ip

Cara menentukan dip yaitu yang pertama menempelkan sisi W (west) badan kompas ke bidang batuan dengan lengan kompas tegak lurus dengan strike. Kedua, mengatur level tabung klinometer hingga tepat di tengah dengan kuas yang berada dibadan kompas. kemudian membaca derajat yang ditunjukkan di klinometer. 


\section{HASIL PENELITIAN}

Hasil identifikasi yang diperoleh dari kuliah lapangan ini yaitu gambar struktur lapisan batuan yang terdapat pada lokasi Mallawa kabupaten Maros. Dapat dilihat gambar berikut ini.

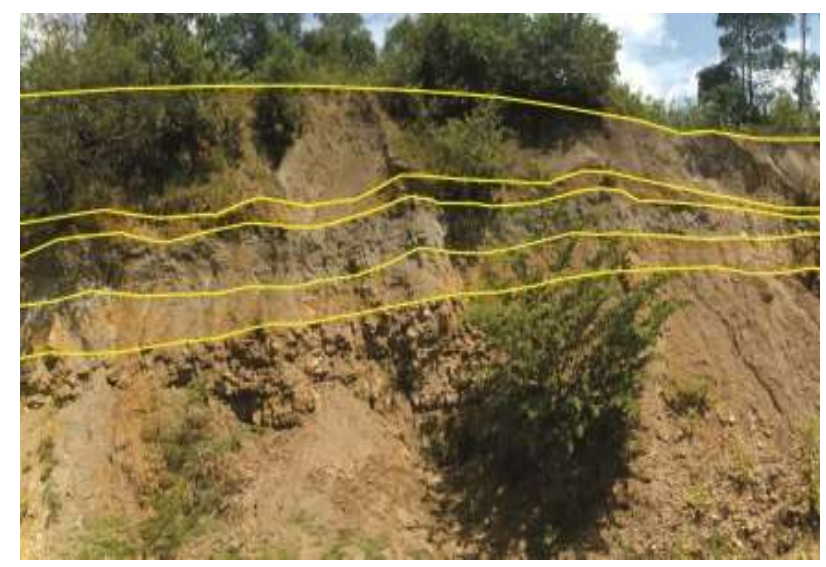

Gambar 5. Kedudukan lapisan batuan

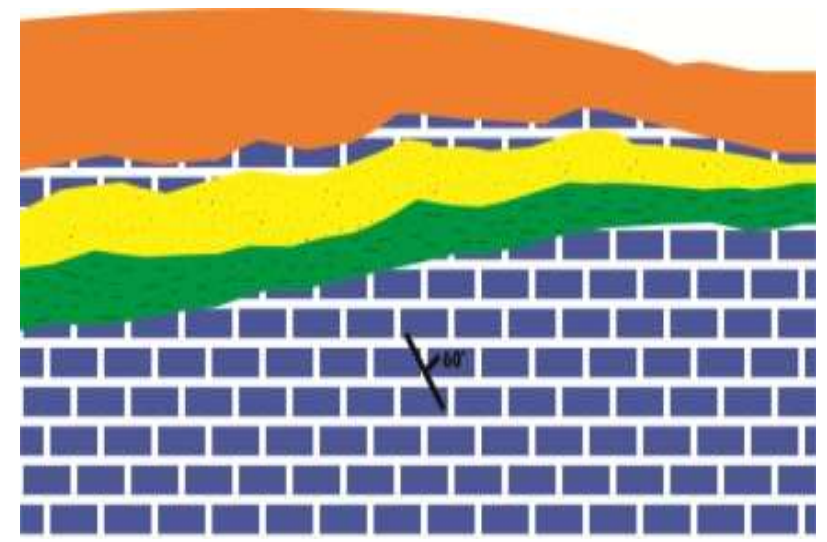

Gambar 6. Kedudukan lapisan batuan

Dari gambar penampang lapisan diatas, dapat diidentifikasi bahwa pada lapisan pertama, diduga sebagai batu rijang karena struktur litologi batuannya berwarna merah maroon dan memiliki ketebalan sekitar 1,2 meter. Untuk lapisan kedua, diduga merupakan batu gamping karena struktur litologi batuannya berwarna orange kecoklatan dan memiliki kedalaman sekitar 0,2 meter. Untuk lapisan ketiga, diduga sebagai batu pasir karena struktur litologi batuannya berwarna abu - abu tua kehitaman dan memiliki tekstur yang agak kasar serta memiliki ketebalan sekitar 0,3 meter. Untuk lapisan keempat merupakn batu lempung karena struktur litologi batuannya berwarna abu-abu muda dan memiliki tekstur yang halus dan menempel di jari pada saat dipegang serta memliki ketebalan sekitar 0,3 meter. Untuk lapisan 
kelima, diduga merupakan batu gamping karena struktur litologi batuannya berwarna coklat muda dan memiliki ketebalan sekitar 1,0 meter.

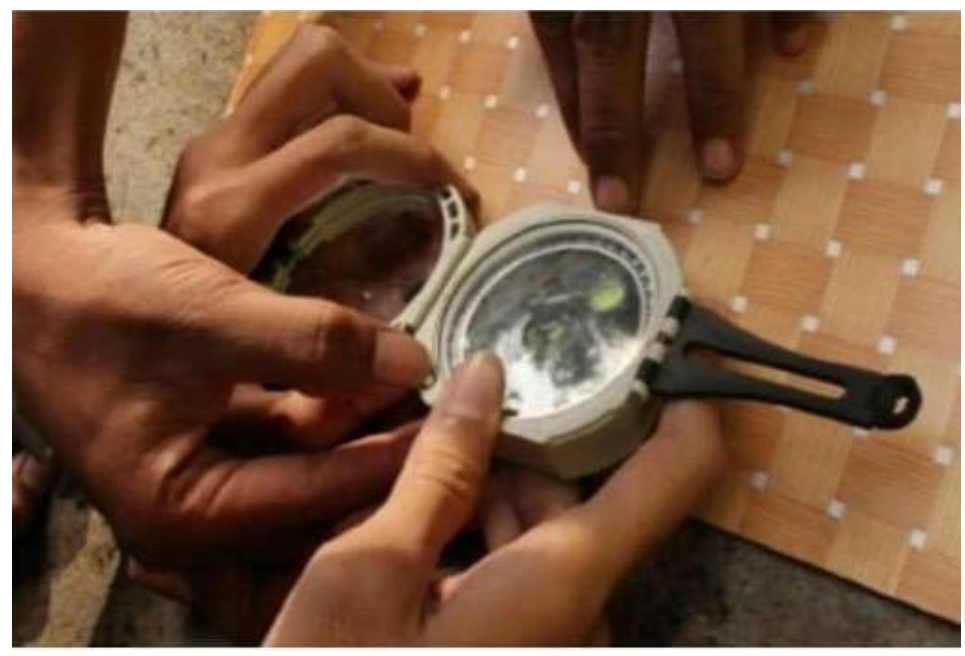

Gambar 5. Pengukuran strike dan dip

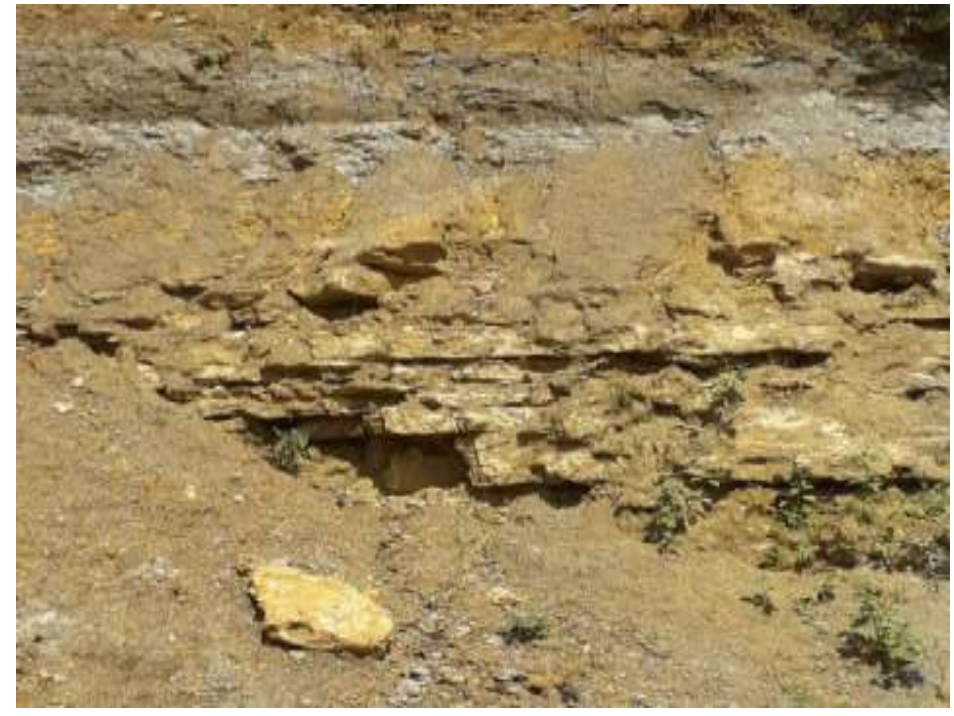

Gambar 6. Lokasi pengukuran

Data yang diperoleh dari hasil pengukuran berupa nilai jurus (Strike) batuan dan kemiringan (Dip) batuan, dimana hasil yang diperoleh berturut-turut sebesar $\mathrm{N}$ $353^{\circ} \mathrm{E} / 64^{\circ}$. Dalam mengukur strike dan Dip ini kita perlu melihat apakah batuan tersebut masih dalam jenis yang sama dan tidak masuk dalam ketegori patahan. Karena akan sangat berbeda nilainya jika kita melakukan pengukuran pada patahan. 
Jurus lapisan yang dilihat langsung dilapangan, umumnya menunjukkan arah timur dan barat lokasi tersebut terdapat perbedaan lapisan batuan, hal ini dapat diduga bahwa pada lokasi tersebut terdapat struktur sesar. Proses tektonik di bagian barat ini berlangsung dari Kala Trias sampai Miosen Awal. Akhir kegiatan gunungapi Miosen Awal itu diikuti oleh tektonik yang menyebabkan terjadinya permulaan terban Walanae yang kemudian menjadi cekungan tempat pembentuk Formasi Walanae. Menurunnya terban Walanae dibatasi oleh dua sistem sesar normal.

Formasi Walanae berhubungan menjari dengan bagian atas Formasi Camba.Kegiatan gunungapi selama Miosen Akhir sampai Pliosen awal merupakan sumber bahan bagi Formasi Walanae.Kegiatan gunungapi yang masih terjadi di beberapa tempat selama Pliosen, dan menghasilkan batuan gunungapi Parepare.Formasi wallanae berumur miosen akhir-pliosen, formasi ini menindih tidak selaras dengan batuan gunungapi formasi camba. Formasi wallanae tersusun dari perselingan batupasir, konglomerat, tufa dengan sisipan batu lanau, batu lempung, batu gamping, napal dan lignit, batupasir berbutir sedang sampai kasar, umunya gampingan dan agak kompak, berkomposisi sebagian andesit dan sebagian lainnya banyak mengandungkuarsa. Tebal satuan ini diperkirakan sekitar 1.200 meter.

\section{KESIMPULAN}

Berdasarkan hasil studi penentuan strike dan dip batuan, dapat disimpulkan bahwa nilai strike dan dip di lokasi kuliah lapangan adalah $N 353^{\circ} \mathrm{E} / 64^{\circ}$.

\section{DAFTAR PUSTAKA}

Alfahak, R.R., 2014. Laporan Fieldtrip Praktikum Geologi Struktur. Diakses pada 03 Juli 2019.

Andromeda, Ebran., 2014. Strike dan Dip:Geologi Struktur. Diakses pada 03 Juli 2019.

Dahayamayanti, Eka, dkk., 2015. Tecno Kompas-Teknologi Kompas Geologi digital dan klinometer Serba Bisa Untuk akuisi Data Pengukuran Strike Div pada Bidang Geologi, Geofisika, dan Arkeologi. Diakses pada 03 Juli 2019.

Hasanuddin, 2017. Situs Neolitik Mallawa Maros, Sulawesi Selatan (Suatu Hasil Analisis Keterkaitan antara Artefak dengan Sumber Daya Lingkungan. Makassar : Balai Arkeologi Makassar.

Husain, J.R.2012. Analisis Struktur Geologi Daerah Maradda Kecamatan Kahu Kabupaten Bone Propinsi Sulawesi Selatan. Diakses pada 03 Juli 2019

Husen, Salahuddin., 2008. Geologi Struktur Latihan Pengolahan Data dan Analisa. Diakses pada 03 Juli 2019.

Jaya, Wangsa. 2015. Peta Geologi.Bandung: ITB .

Sukartomo, 2013. Buku Panduan Praktikum Geologi Struktur. Yogyakarta: Sekolah Tinggi Teknologi Nasional. 